Journal of Nepal Geological Society, vol.2, Special Issue, 1982, 149-155

\title{
JURASSIC AMMONITES FROM THE MUKTINATH REGION, CENTRAL NEPAL
}

\author{
Kotaro Kamada, Kazunori ARITA and Mitsuo YoshidA \\ Department of Geology and Mineralogy, Hokkaido University, Sapporo 060, Japan
}

\begin{abstract}
Three species of Oxfordian ammonites, Epimayaites aff. lemoini(Spath), Paryphoceras badiense Spath and Dichotomosphinctes subhelenae Spath, are described and figured from the Muktinath region, of Central Nepal. They are all identified with the forms known from Cutch $(=K u t c h)$, and are the elements of Ethiopian "Province" of Hallam(1971).
\end{abstract}

\section{INTRODUCTION}

During 1980-1981, Arita and Yoshida, as a part of the project called "the Study on Crustal Movements of the Nepal Himalayas," engaged in a geological survey of Thakkhola area in the upper stream of Kali Gandaki river, Central Nepal. At that time they collected some belemnites, pelecypods and ammonites from scattered localities of Jurassic strata, exposed within the Muktinath region, Thakkhola.

The present article describes the three ammonite species, represented by three specimens from three different localites.

The region has long been known for yielding ammonites, which are often contained in nodules called "Saligram" in Sanskrit (Reed,1908; Arkell,1956; Hagen,1968).

In spite of the common occurrence of ammonite in the Muktinath region, they have been only briefly described by Reed (1908). Specimens mentioned by Reed, now stored at the Sedgwick Museum of Cambridge, are later reexamined and listed by Arkell (1956,p.414). Bordet et al. (1971) further listed up a number of ammonites from many scattered localities within the region. Several conspicuous forms are illustrated in Bordet et al. (1971). Also according to Gansser (1964), Ryf (1962) described and figures the genus Haplophylloceras from the same region.

But the specimens at hands are not recorded or illustrated by the previous authors, and thus merit description.

The following three species are identified.
Epimayaites aff. lemoini (Spath)
(Loc.02, Fig.1)
Paryphoceras badiense Spath
(Loc.01, Fig.1)
Dichotomosphinctes subhelenae Spath
(Loc.03, Fig. 1)

\section{GEOLOGICAL SETTING}

The Thakkhola area in the upper tributaries of Kali Gandaki (or Krishna Gandaki) river belongs geologically to the Tethyan Zone of Nepal (Hagen,1968; Gansser,1964; Bordet et al.,1971). There occurs a very thick sequence of rock series ranging from Precambrian to Quaternary. Fossils are by no means 


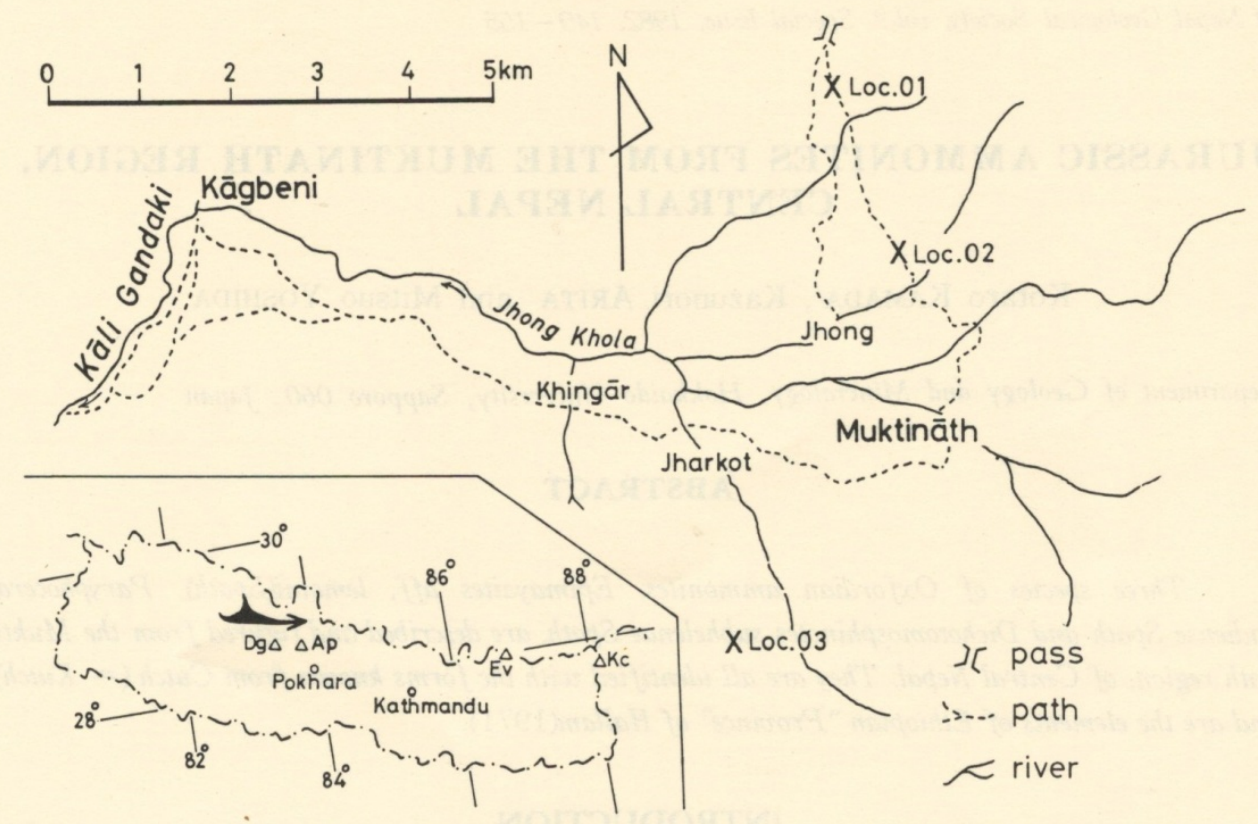

Fig.1 Map showing the fossil localities.

Dg: Dhaulagiri Ap: Annapurna Ev: Mt.Everest Kc: Kangchenjunga

common in them, but the evidence is clear for the presence of Ordovician, Silurian, Devonian, Carboniferous, Permian, Triassic, Jurassic and Cretaceous (Bordet et al.,1971).

The Jurassic is divided into three units,namely the Lower, Middle and Upper units. As a whole, it is marine and at the same time shallow basin facies, except for "Spiti Shales". The Lower Jurassic is mainly composed of limestone, but without any positive fossil evidence. The Middle Jurassic is composed of the alternation of limestone and sandy bed, yielding Bajocian to Lower Callovian ammonites. The Upper Jurassic is mainly composed of black shale with argillaceous nodules contains ammonites. This black shale corresponds to the "Spiti Shales", is rich in organic material, and bituminous. The "Spiti Shales" is overlain by the plant bearing Lower Cretaceous sandstone beds. The present specimens of ammonite are all obtained from this black "Spiti Shales". This black shale is generally splintery by weathering, crops out as isolated exposures within the covering of morainic debris.

"Spiti Shales" and its equivalent facies have been widely traced throughout the whole Himalayas (Arkell,1956; Gansser,1964;Wadia,1973). Many Oxfordian to Neocomian ammonites are described from the "Spiti Shales" (e.g. Uhlig,1903-10). Hagen (1968) proposed the name of Saligram Series for the Thakkhola "Spiti Shales" which was however found to incorporate even Paleocene (Gansser, 1964).

\section{SYSTEMATIC DESCRIPTION *}

Order Ammonoidea

Superfamily Stephanocerataceae Neumayr, 1875

Family Mayaitidae Spath, 1928

Genus Epimayaites Spath, 1928

\footnotetext{
* Suprageneric classification adopted here is after Arkell et al. (1957).
} 


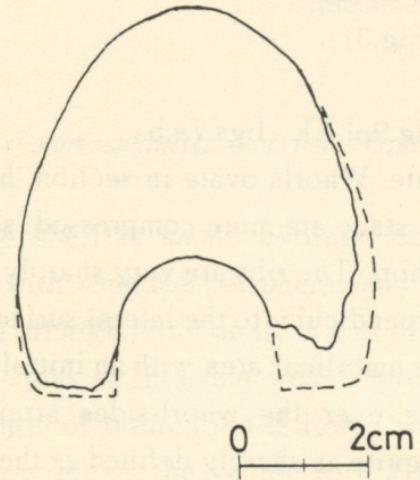

Fig.2 Whorl-section of Epimayaites aff. lemoini (Spath), figured Pl.1, Figs.1a,b.

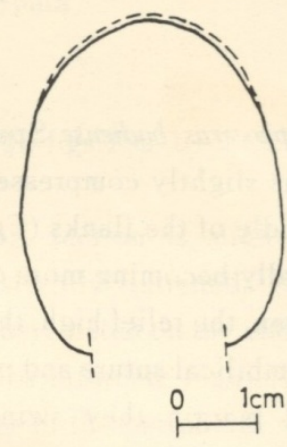

Fig.3 Whorl-section of Paryphoceras badiense Spath, figured Pl.1, Figs.2a,b,c.

Type species: Stephanoceras transiens Waagen, 1875

Epimayaites aff. lemoini (Spath)

(Pl.1,Figs.1a,b; Fig.2)

1928. Epimayaites aff. lemoini Spath,p.234,pl.XXVI,figs.4a,b.

Description: Shell evolute. The whorl-section (Fig.2) is thickest close to the umbilical margin, the sides very gently rounded, the ventral face almost semicircular, embracing most of the preceding whorl. The umbilical area is wide. The primary ribs are rounded, not in high relief, and sloping away gently into the surface from which they rise, and broaden slightly towards the point of bifurcation, which lies half-way across the whorl-side. The mode of bifurcation is somewhat irregular. The majority of the secondaries take aff symmetrically from the primaries. The secondaries are slightly feebler than the primaries. They are stightly inclined forward and on the ventral face. They form an anteriorly convex arch. Most rib branches are separated by single intercalary ribs which begin at or slightly above the line of furcation. The intercalatory rarely seems partially to fuse with one of the byplicate pairs and give rise to trifurcation. There is a simple primary rib.

Messurements: The dimensions connot be stated with certainty because it is imcompletely preserved. Pmark: The material is a single specimen with about three quarters of the whorl missing. Inner two whorls ane septate. And the specimen is identical with Epimayaites aff. lemoini (Spath). In his paper (Spath,1928) wo specimens are illustrated for Epimayaites lemoini. Among them one (pl.XXVI,figs.4a,b) is in the aplanation actually called as Epimayaites aff. lemoini, and mentioned in the text as a form transitional to Eumaryaites axonoides. This is the form to which the present specimen is conspecific. Epimayaites lemoini = Sophanoceras maya of Waagen) has relatively finer ribs compared to Epimayaites aff. lemoini. Epimayaites armiles Spath has a little coaser,curved ribs and less compressed whorl compared to Epimayaites aff. imurizin

Eprimayaites aff. lemoini (Spath) is obtained from the Kantcote sandstone of Cutch (India). And Eumaryies aff. lemoini is listed by Bordet et al.(1971) from a locality about $2 \mathrm{~km}$ south of the present place. Drevmence: From the black splintery shale of the lower part of the "Spiti Shales" Loc.02, north Muktinath.

Genus Paryphoceras Spath,1928

Type species: Paryphoceras badiense Spath,1928 
1928. Paryphoceras badiense Spath,p.248,pl.XXXV,fig.9pl.XL, figs.7a,b.

Description: Shell is slightly compressed, moderately evolute. Whorls ovate in section, higher than wide, thickest at the middle of the flanks (Fg.3). Flanks in early stage are more compressed, slightly flattened, smooth and gradually becoming more convex in the last whorl. The ribs are very sharply defined on fresh part of this specimen, the relief high, the side of the ribs perpendicular to the lateral surface. The primaries originated at the umbilical suture and pass strongly over the umbilical area with an initial backward curve. On the umbilical margin they swing forward and pass over the whorl-sides straight but weakly prorsiradiate. The secondary ribs are almost as strong and quite as sharply defined as the primaries. They take of near the middle of the flanks, and separated irregularly by one intercalatorny that begin along the zone of furcation, which seems partially to fuse with one of the biplicate pairs and give rise to trifurcation. The secondary of each pair takes off forwards and in places develops a considerable forward sweep on the venter. Suture unknown.

Measurements:

$\begin{array}{ll}\text { Maximum diameter } & 94.0 \mathrm{~mm} \\ \text { At } & 91.6 \mathrm{~mm} \\ \text { Height of whorl } & 41.8 \mathrm{~mm} \\ \text { Thickness of whorl } & 34.3 \mathrm{~mm} \\ \text { Width of umbilicus } & 19.8 \mathrm{~mm}\end{array}$

Remarks:The Muktinath specimen is a corroded individual from the nodule at the Loc.01, lacks the sutures. The ornamentation of the whorls are, however, well preserved for the identification of species. The distinct ornamentation of the shell and their characteristic features are enough to identify it with the present species. But the Muktinath specimen is slightly different from the Spath's holotype (1928,p.248,pl.XL,figs.7a,b) from the Upper Oxfordian Dhosa Oolite, of Badi and Fakirwadi, Cutch( $=$ Kutch), in having greater whorl-thickness of the last part of the whorl by reason of corroded ventral margin of the Cutch specimen. Paryphoceras rugosum Spath resembles Paryphoceras badiense Spath, but the former is less flexi-costate, with less pronounced peripheral projection, smaller umbilicus. Paryphoceras badiense also somewhat resembles Prograyiceras grayi Spath. But the genus Prograyiceras has more inflated shell with much pronounced costation than in Paryphoceras. In general Paryphoceras morphologically stands in between Prograyiceras and Mayaites in the family Mayaitidae. Paryphoceras stephanoides Spath appears to the authors more similar to Prograyiceras or Dhosaites in the surface shell ornamentation in revealing strong ribbing. From the Muktinath region several form of Grayiceras? and Prograyiceras are recorded previously by Bordet et al. (1971).

Occurrence: One specimen,from Loc.01, northernwest of Muktinath, from a nodule derived from the exposure of black splintery shale of the upper(?) part of the "Spiti Shales"

Superfamily Perisphinctaceae Steinmann, 1890

Family Perisphinctidae Steinmann,1890

Subfamily Perisphinctinae Steinmann,1890

Genus Dichotomosphinctes Buckman, 1925

Type species: Perisphinctes antecedens Salfeld,1914 


\section{Dichotomosphinctes subhelenae Spath}

(Pl.I, Figs.3a.b.c.)

1931. Dichotomosphinctes subhelenae Spath, p.437, pl.LXXXVII, figs.10a, b; pl.CI, figs.2, 3, 4a, b, 10a, b.

Description: The shell is small, evolute, compressed. The whorl section is slightly quadrate, nearly parallel-sided, with rounded peripheral and umbilical margins, slightly flattened. The ribs are slender, fairly sharp and off high relief on fresh part of the specimen. They originated on the umbilical area and pass over the whorl-sides straight but weakly prorsiradiate. All the ribs bifurcate regularly on the peripheral margin. The angle of bifurcation is low. Ribbs are a little feebler in the peripheral region. They branch forward and pass across the venter with a well-marked forward sweep. There are two irregularities of ribbing caused by wide spaced that may correspond with the constrictions.

Measurements :

\begin{tabular}{ll} 
Maximum diameter & $85.4 \mathrm{~mm}$ \\
Height of whorl & $68.3 \mathrm{~mm}$ \\
Thickness of whorl & $22.3 \mathrm{~mm}$ \\
Width of umbilicus & $21.0 \mathrm{~mm}$ \\
\hline & $29.2 \mathrm{~mm}$
\end{tabular}

Remarks: Only one, somewhat squashed specimen is available. The specimen lacks the sutures, but ornamentation of the whorls, as well as the general shape and characters of the venter are well preserved. On the basis of those features the specimen is clearly identifiable with Dichotomosphinctes subhelenae Spath. In the present specimen the furcation point of ribbs starts about two thirds of the distance on the whorl side from the umbilical suture. Spath's type material is however all septate, small, and shows this furcation point more close to the periphery. Dichotomosphinctes subhelenae is first distinguished from Dichotomosphinctes helenae (de Riaz) by Spath (1931) in having broad umbilicus and sharp secondaries. He states that this species is transitional from Dichotomosphinctes helenae to Dichotomosphinctes grossouvrei (Siemiradzki).

Previously, no species of Dichotomosphinctes has been found from the Muktinath region. Bordet et al. (1971) lists Arisphinctes gr. helenae (de Riaz) from northeast of Jomosom, Thakkhola Area. It may be a form similar to the present specimen.

Occurrence: One specimen, from black splintery shale of the "Spiti Shales" southwest Muktinath (Loc.03).

\section{FAUNAL CONSIDERATION AND CORRELATION}

Three species of ammonite are identified from the isolated localities 01 to 03 near Muktinath in the Thakkhola area. They are Epimayaites aff. lemoini (Spath), Paryphoceras badiense Spath and Dichotomosphinctes subhelenae Spath. Epimayaites lemoini Spath (= Stephanoceras maya of Waagen) and Epimayaites aff. lemoini Spath have been known from the Oxfordian Kantcote sandstone of Cutch. According to Spath (1933) and Arkell (1956), Epimayaites lemoini belongs to the Bimammatum zone of upper Oxfordian (Argovian). Epimayaites aff. lemoini is also recorded by Bordet et al.(1971) from the Muktinath region and Epimayaites cfr. lemoini is listed by Arkell (1956) from Mombasa, Kenya. Both Paryphoceras badiense Spath and Dichotomosphinctes subhelenae Spath have been described by Spath (1928) from the Dhosa Oolite of Cutch, which is Transversarium zone (=Plicatilis zone) of upper Oxfordian.Dichotomosphinctes is, as other perisphinctid genera, widely distributed in the Upper Jurassic of the World. Paryphoceras badiense has not been known from elsewhere but the genus is represented also in Madagascar.

As far as described forms are concerned the Muktinath fauna shows very close relationship with the 
upper Oxfordian ammonites of Cutch. Mayaitids in general have been known from Dar-es-Salaam (Tanzania), Mombasa, Cutch and Indonesia in the eastern Tethys (Arkell,1956). And it is thus evident that the Muktinath region yielding such ammonite genera as Epimayaites, Pariphoceras, Prograyiceras, etc. is within the Ethiopian "Province" of Hallam (1971) in the Upper Jurassic.

\section{ACKNOWLEDGEMENTS}

We express our deep gratitude to Professor Makoto Kato of Hokkaido University for critically reading the manuscript.

\section{REFERENCES}

Arkell, W. J., 1956. Jurassic geology of the world. XV+806pp., 46pls., 27 tables, 102figs. Oliver and Boyd, Edinburgh.

Arkell, W. J., Kummel, B. and Wright, C. W., 1957. Mesozoic Ammonoidea. In R.C.Moore (ed.) Treatise on invertebrate paleontology, Part L, p.L80-L465, Univ. Kansas Press, Lawrence.

Bordet, P., Colchen, M., Krummenacher, D., LeFort, Mouterde, R. and Remy, M., 1971. Recherches geólogiques dans l'Himalaya du Népal, région de la Thakkhola. Ed.C.N.R.S.,279p., 1 carte.

Gansser, A., 1964. Geology of Himalayas. Interscience Publishers, London, 289p.

Hagen. T., 1968. Report of the geological survey of Nepal. II: Geology of Thakkhola, including adjacent areas. Mem. Soc. Helv. Sc. Nat., T.86, 160pp.

Hallam, A:, 1971. Provinciality in Jurassic faunas in relation to facies and palaeogeography. In Middlemiss,F.A., Rawson, P.S. and Newall,G. (eds.) Faunal Provinces in Space and Time. 129-152. Seel House, Liverpool.

Reed, F. R. C., 1908. Fossils from Nepal. Geol. Mag., N.S.,5(5), 256-261.

Ryf, W., 1962. Über das Genus Haplophyllocepas (Ammonoidea) in den Spiti-Shales von Nepal. Ecl. geol. Helv., 55(2), 318-325, 3text-figs, Taf.1-2.

Spath, L.F., 1927-33. Revision of the Jurassic cephalopod fauna of Kutch (Cutch). Men. geol. Surv. India, (Pal. Indica), N.S., 9(2), 1-945, 130pls.

Uhlig, V., 1903-1910. The fauna of the Spiti Shales. Mem. Geol. Surv. India, (Pal.Indica), 15(4), 1-359, 93pls.

Waagen, W., 1873-75. Jurassic Fauna of Kutch. Mem. Geol. Surv. India, (Pal. Indica), 9(1), 1-247, 60pls.

Wadia, D. N., 1973. Geology of India. 4th ed., MacMillan,London, 536pp.

Figs.1a,b: Epimayaites aff. lemoini (Spath) la,View of the external periphery. 1b,Lateral view. $\times 0.8$.

Figs.2a,b: Paryphoceras badiense Spath. 2a,View of the external periphery. 2b,Lateral view. $\times 0.8$.

Figs.3a-c: Dichotomosphinctes subeelenae Spath 3a,View of the external periphery. 3b,Apertural view. $3 c$, Lateral view. $\times 0.8$.

All specimens illustrated here are kept in the Department of Geology and Mineralogy, Hokkaido University, Sapporo. 

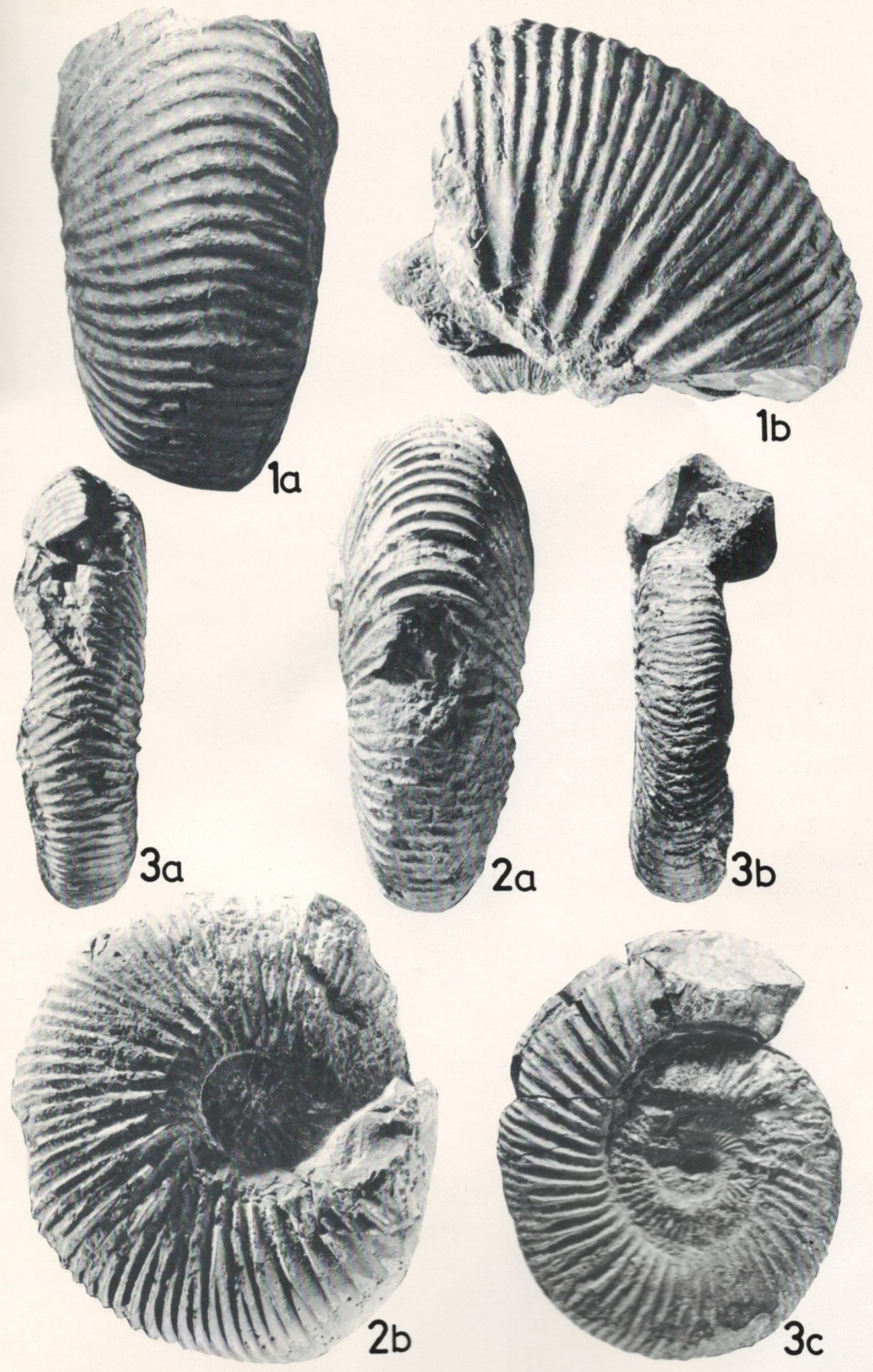